\title{
Potential Radioprotective Effect of AT Receptor Antagonists Against Morphological and Ultrastructural Changes in the Testes Induced by Ionizing Radiation
}

\author{
Potencial Efecto Radioprotector de Antagonistas del Receptor AT 1 Contra los Daños \\ Morfológicos y Ultraestructurales en los Testículos Inducido por la Radiación Ionizante \\ Franciele Cristina Schwarz ${ }^{1}$; Naira da Silva Mansano² ${ }^{2}$ Agnaldo Bruno Chies $^{3}$; \\ Gustavo Arruda Viani ${ }^{4}$ \& Maria Angélica Spadella ${ }^{3}$
}

SCHWARZ, F. C.; MANSANO, N. S.; CHIES, A. B.; VIANI, G. A. \& SPADELLA, M. A. Potential radioprotective effect of AT receptor antagonists against morphological and ultrastructural changes in the testes induced by ionizing radiation. Int. J. Morphol., 35(3):820-830, 2017.

SUMMARY: Radiotherapy is a source of human exposure to ionizing radiation. This pure energy causes deleterious effects on tissues, which result from oxidative stress, a phenomenon in which there is the participation of the Renin-Angiotensin System (RAS). The male genital organs are extremely radiosensitive and the action of radiation in the testes can significantly affect spermatogenesis. In search of potential radioprotective for male genital system, this study investigated whether the AT receptor antagonists minimize radiationinduced damage to reproductive tissues, by decreasing oxidative stress. Male Wistar rats were divided into six groups: 0 Gray (Gy) (control), 5 Gy (single dose in the scrotal area), telmisartan, losartan, 5Gy+telmisartan and 5Gy+losartan. The treatment started the day after irradiation with losartan $34 \mathrm{mg} / \mathrm{kg}$ (two times/day) and telmisartan $12 \mathrm{mg} / \mathrm{kg}$ (one time/day) during 60 days. For ultrastructural analysis, the testis fragments were fixed in $2 \%$ glutaraldehyde and $4 \%$ paraformaldehyde in $0.1 \mathrm{M}$ phosphate buffer, $\mathrm{pH} 7.3$. The material was postfixed for $2 \mathrm{~h}$ in $1 \%$ osmium tetroxide. For collagen evaluation, the sections were stained with Picrosirius-red method. Serum testosterone was determined. The date showed the deleterious effects of gamma radiation on testicular ultrastructure. Rich accumulation of collagen fibers in the interstitium was observed in the irradiated groups, especially the irradiated and nontreated testes. No significant difference was detected in serum testosterone concentration among the studied experimental groups. Treatments with telmisartan and losartan influenced the onset of attenuation on ultrastructural damages arising from ionizing radiation. Although the data strongly suggest that $\mathrm{AT}_{1}$ receptor antagonists may promote radioprotection to the testes, further studies with a longer duration of treatment are required for these potentially positive effects to be maximized and, therefore, to better characterize radioprotection to reproductive parameters.

KEY WORDS: Ionizing radiation; Testicular ultrastructure; Spermatogenesis; Renin-angiotensin system; Oxidative stress; Angiotensin II type 1 receptor blockers.

\section{INTRODUCTION}

The widespread use of radiotherapy for cancer treatment is undoubtedly a major source of human exposure to ionizing radiation. In male patients, radiation can cause temporary or permanent infertility/sterility related to nonnormal cyclic process of spermatogenesis (Meistrich, 2013).

Many studies have shown the impact of gamma radiation in the male fertility in both rat and human (Koruji et al., 2008; Topcu-Tarladacalisir et al., 2009; Kanter et al.,
2010; Kim et al., 2012; Meistrich). Previous evidence relate that the apoptosis of germ cells is the main mechanism responsible by infertility in irradiated testes, due to the ionizing radiation lead to the increase of the number of these deaths as a consequence of oxidative stress (Kanter et al.).

The classic role of renin-angiotensin system (RAS) relates to the maintenance of electrolyte and fluid homeostasis and blood pressure (Benigni et al., 2010).

\footnotetext{
${ }^{1}$ Pós-graduanda, Mestrado Acadêmico Saúde e Envelhecimento, Faculdade de Medicina de Marília - FAMEMA, Marília, Brazil.

${ }^{2}$ Mestre em Saúde e Envelhecimento, Faculdade de Medicina de Marília - FAMEMA, Marília, Brazil.

${ }^{3}$ Docentes do Programa de Mestrado Acadêmico em Saúde e Envelhecimento, Faculdade de Medicina de Marília - FAMEMA, Marília, Brazil.

${ }^{4}$ Médico, Radioterapia e Oncologia, Universidade de São Paulo, Ribeirão Preto, Brazil.

This research was supported by Brazilian agency - FAPESP (Fundação de Amparo à Pesquisa do Estado de São Paulo), grant \#2015/20740-4.
} 
However, studies have shown intrinsic synthesis of RAS components in the male reproductive tissues, with evidences of its participation in physiological process such as spermatogenesis (Speth et al., 1999; Leung \& Sernia, 2003). Leung \& Sernia summarize the local RAS role in different regions of the male genital system.

In irradiated tissues, the pathogenic role of the RAS in modulating of late effects arising from free radicals is evidenced in studies (Nair et al., 2001; Robbins \& Zhao, 2004; Robbins \& Diz, 2006). This is because both ionizing radiation and Angiotensin II (AngII) mediate their biological responses through the generation of reactive oxygen species (ROS), either directly or indirectly by the activation of proinflammatory mediators, resulting in damage and cellular dysfunction. It is suggested that AngII by binding to the AT1 receptor, increases the activity of the nicotinamide adenosine dinucleotide phosphate (NADPH) oxidase that contribute to ROS generation and, consequent tecidual oxidative stress (Robbins \& Diz).

In male reproductive tissues, the oxidative stress resulting of NADPH oxidase hyperactivity is considered the most influential damaging factor to the testicular function (Li et al., 2013). Although the male genital system has protector mechanisms against oxidative stress for maintenance of reproductive viability (Bauché et al., 1994; Fujii et al., 2003), the ROS production through radiation and NADPH oxidase activity exceed the tecidual antioxidant capacity (Robbins \& Diz; Robbins \& Zhao).

Considering that RAS can be involved in the pathogenesis of radiation-induced changes, inhibitors of this system have been used in the prevention and/or reduction of the severity of these tecidual damages, acting as radioprotectors. There are evidences of that angiotensinconverting enzyme inhibitors (ACEIs) and AT1 receptor antagonists (AT1RAs) were effective in the prophylaxis of late radiation-induced injury in lung, kidney and brain, organs with an intrinsic RAS, acting against oxidative stress by blocking the formation of free radicals and reduction of chronic inflammation (Nair et al.; Robbins \& Diz; GreeneSchloesser et al., 2012; Kharofa et al., 2012).

Although the potential radioprotective effect of these pharmacologic agents was observed in other tissues, their action in irradiated reproductive tissues is not yet understood, since the male genital system also posses an intrinsic RAS. Thus, the aim of this study was to evaluate the morphological and ultrastructural effects of ionizing radiation on the testes, and to verify if the AngII AT1 receptor antagonists can mitigate the testicular damages resulting from this exposure.

\section{MATERIAL AND METHOD}

Animals. Fifty-one male Wistar rats (Rattus norvegicus albinus), of 9 to 10 weeks age, weighing about $300 \mathrm{~g}$, were obtained from the Central Biotery of Marília Medical School - FAMEMA. The rats were kept under standard conditions of temperature (around $23 \pm 1^{\circ} \mathrm{C}$ ) and lighting (12/12 h light/ dark cycle), with access ad libitum to water and pelleted rodent chow. This study was approved by the Ethics Committee on Animal Experimentation (CEUA/FAMEMA, protocol number 552/14).

Experimental Groups. The male Wistar rats were randomly divided into six groups, as described: Control $(n=9)$ : nonirradiated and non-treated (vehicle); 5 Gy $(n=7)$ : irradiated and non-treated (vehicle); Telmisartan $(n=9)$ : non-irradiated and treated with telmisartan; Losartan $(n=9)$ : non-irradiated and treated with losartan; $5 \mathrm{~Gy}+$ Telmisartan $(\mathrm{n}=9)$ : irradiated and treated with telmisartan; $5 \mathrm{~Gy}+$ Losartan (n $=8$ ): irradiated and treated with losartan.

Irradiation Protocol. Rats were anesthetized with a mixture of Ketamine-xylazine $(70 / 7 \mathrm{mg} / \mathrm{kg}$ body weight, i.p., respectively) and immobilized from their 4 extremities on a Styrofoam plate. The radiation was delivered to a distance of $65 \mathrm{~cm}$, using the linear accelerator (Clinac $6 \mathrm{EX} 6 \mathrm{MV}$ VARIAN, USA). According to Kim et al., a single dose of 5 Gy (dose rate of $1.05 \mathrm{~Gy} / \mathrm{min}$ ) was effectuated at a depth of $2.0 \mathrm{~cm}$, directly at a field scrotal of $5 \times 5 \mathrm{~cm}$, antero-posterior direction, in supine position. Except by exposure to radiation, the animals from controls groups were submitted to the same procedures.

Treatment. The treatment started on the day following irradiation by administration of $12 \mathrm{mg} / \mathrm{kg}$ telmisartan (Kushwaha \& Jena, 2013) (commercial product Micardis ${ }^{\circledR}$ ), one time per day and $34 \mathrm{mg} / \mathrm{kg}$ losartan (Kharofa et al.) (pure form from Gemini/Brazil), two times per day. The drugs were freshly prepared in $0.5 \%$ carboxymethyl cellulose and were administered by gavage for 60 consecutive days. The control and $5 \mathrm{~Gy}$ groups were also submitted to gavage for administration of vehicle (two times/day). During the treatment, the rats were daily weighed.

Tissue preparation for electron transmission microscopy analysis. To the end of experimental protocol, the rats were weighed and anesthetized with ketaminexylazine, and euthanized by exsanguination of the inferior vena cava. The left testes from each animal were dissected and weighed with the tunica albuginea. Testis fragments (approximately $1 \mathrm{~mm}$ ) were fixed in $2 \%$ glutaraldehyde 
and $4 \%$ paraformaldehyde in $0.1 \mathrm{M}$ Sorensen phosphate buffer, $\mathrm{pH} 7.4$ for 24 hours. After, the fragments were removed from the fixative and washed in the same buffer. Next, the material was postfixed in $1 \%$ osmium tetroxide, dehydrated in acetone and embedded in epoxy resin. Ultrathin sections were obtained and contrasted (in dark) with saturated uranyl acetate in $50 \%$ alcohol and lead citrate. The samples were observed and photographed with a transmission electron microscope (Tecnai Spirit - FEI Company).

Collagen evaluation. Other testis fragments from each animal were fixed in $4 \%$ formaldehyde in $0.1 \mathrm{M}$ Phosphatebuffered saline (PBS), pH 7.4 for 24 hours. After fixation, the samples were washed with tap water for 24 hours to remove excess fixative. Subsequently, the material was processed for embedding in Paraplast plus ${ }^{\circledR} .5 \mu \mathrm{m}$ sections were stained with Picrosirius-red method (Montes \& Junqueira, 1991; Morais et al., 2017) and analyzed under polarized light for qualitative evaluation of collagen.

Determination of serum testosterone. Blood samples were collected from the inferior vena cava of each rat and immediately placed in plastic blood collection tubes, which were kept at room temperature for 30 minutes. Serum was obtained by centrifugation $\left(3000 \mathrm{rpm}, 10 \mathrm{~min}\right.$ at $4{ }^{\circ} \mathrm{C}$ ) and stored at $-20^{\circ} \mathrm{C}$ until assayed. Hormone level was measured by chemiluminescence method (São Camilo Laboratory, Veterinary Division, Maringá, PR, Brazil). Serum testosterone was expressed in $\mathrm{ng} / \mathrm{mL}$.

Statistical analysis. The serum testosterone data were expressed as the mean \pm standard desviation (SD). Normal distribution of data was tested using Shapiro-Wilk test and the homoscedasticity by Bartlett test. Two-way analysis of variance (ANOVA) followed by the Tukey test was used for multiple comparisons. Values of $\mathrm{p}<0.05$ were considered statistically significant. All data analyses were done using GraphPadPrism ${ }^{\circledR}$ software, v. 6.01, USA.

\section{RESULTS}

Body and testes weights. There was significant decrease in body weight from $5 \mathrm{~Gy}+$ Telmisartan in comparison with Telmisartan group. Relative to testes, the ionizing radiation caused significant decrease in the wet weights in all irradiated groups, nontreated or treated (Date not show).

Ultrastructural study of the testes. Testicular ultrastructure differed markedly between the irradiated groups and their respective controls (Figs. 1-4).
The testes of the Control, Telmisartan and Losartan groups showed normal tissue structure, containing numerous seminiferous tubules interspersed with interstitial tissue. The seminiferous tubules were classically structured, with central lumen, and coated by the seminiferous epithelium and Sustentocytes cells. The seminiferous epithelium was intact and displayed normal spermatogenic activity, as it contained germ cells at various stages of maturation. Peritubular myoid cells with normal morphology were separated from the seminiferous epithelium by the basement membrane, representing typical organization. Sustentocytes cells showed normal distribution in the seminiferous tubules, being supported on the basal lamina along with the spermatagonia. The nuclei of these cells exhibited typical columnar or triangular shapes (Figs. 1a-d, 2a-d, 3a-d). The blood-testis barrier was found to have normal organization between the basal and adluminal compartments of the seminiferous tubules. Interstitial endocrine cell aggregates, blood vessels, lymphatic space and macrophages - all of normal morphology — were observed in the interstitial region (Figs. 4a-c).

On the other hand, ultrastructural analysis of the testes from the irradiated groups showed degeneration of the seminiferous tubules, with vacuolization of the seminiferous epithelium. In the 5 Gy group, we observed completely degenerated seminiferous tubules with significant tissue impairment. The seminiferous epithelium was degenerated due to extensive loss of cells of spermatogenic lineage, resulting in the appearance of vacuoles of varying sizes. These vacuoles formed in the intercellular space between adjacent Sustentocytes cells, with the location corresponding to the area that was occupied by the germ cells. As a result, the bloodtestis barrier was broken down (Figs. 1e-h).

No signs of spermatogenic activity were observed in the seminiferous tubules, and there were no spermatozoa in the lumen. The only surviving cells observed were the Sustentocytes cells, in higher proportion, and exceedingly rare spermatagonia (stem cell), which showed signs of abnormal morphology and degeneration of the cytoplasmic organelles. Ionizing radiation promoted significant alterations in Sustentocytes cell morphology. The nuclei of these cells exhibited irregular shape, with various invaginations of the nuclear membrane. In addition, Sustentocytes cells were sparsely distributed in the seminiferous tubules, and in several cases, also distanced from the basement membrane (Figs. 1e-h).

The basement membrane of the seminiferous tubules appeared extremely thick, with numerous folds in the direction of the seminiferous epithelium. Also, the peritubular myoid cells exhibited irregularly shaped nuclei that were not of the characteristic elongated form (Figs. 1a, 1g-h). 


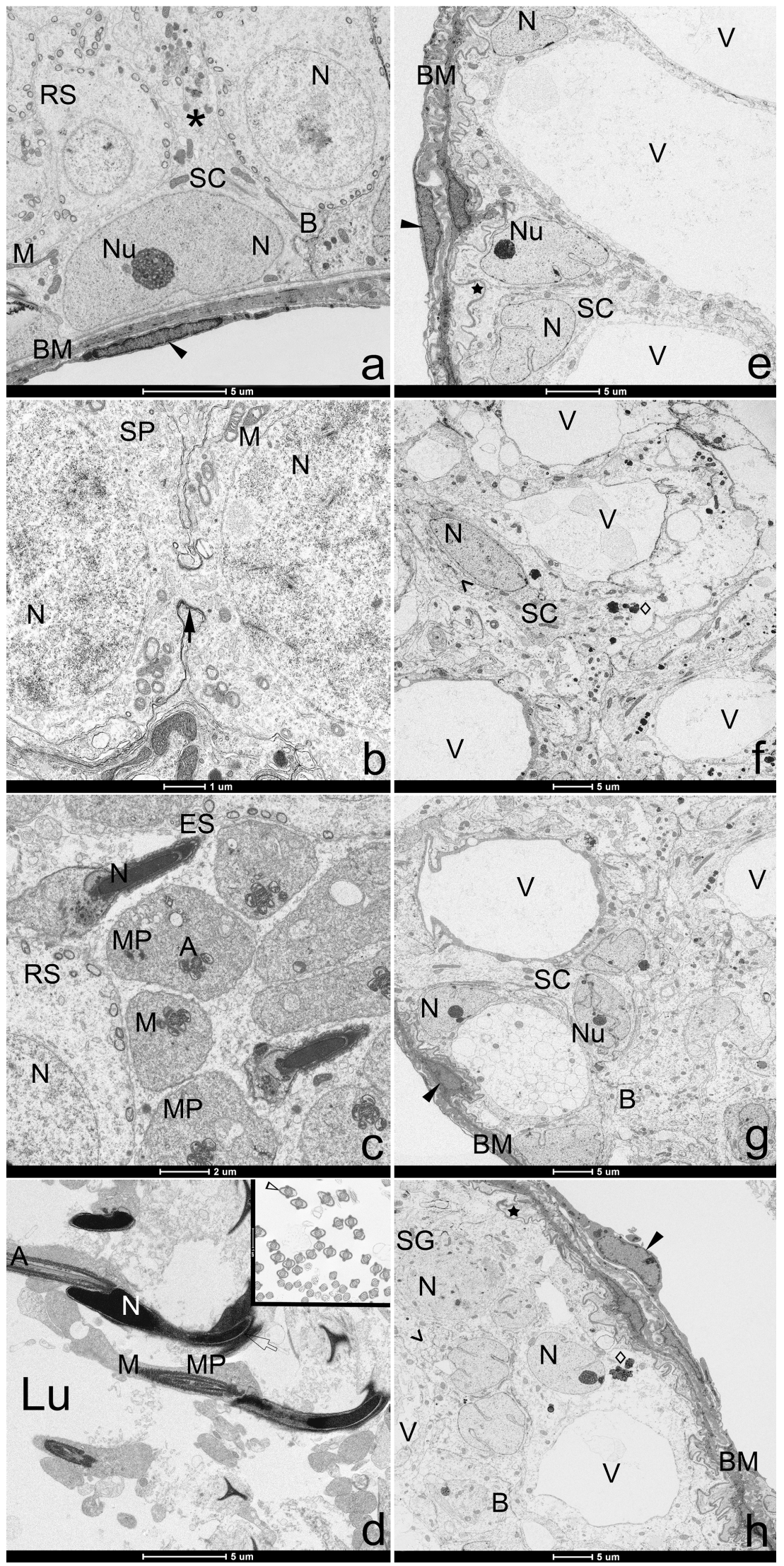

In the interstitial region of the irradiated testes, Insterstitial endocrine cell aggregates with morphology similar to those of the control animals were observed. However, the interstitial tissue between the seminiferous tubules was enlarged and richly vascularized. Some of the observed blood vessels showed alterations in their histological structure, especially in the endothelial cells, as well as tissue retraction (Figs. 4a-f). Concerning the pharmalogical treatment, ultrastructural analysis revealed that most of the seminiferous tubules from the $5 \mathrm{~Gy}+$ Telmisartan and 5 Gy + Losartan groups also exhibited degeneration of the seminiferous epithelium, vacuolization and changes in

Fig. 1. Transmission electron micrographs of testes from control (a-d) and irradiated with 5 Gy rats (e-f). a. Sustentocytes cell (SC) with a electron-lucent nucleus $(\mathrm{N})$ and a proeminente nucleolus $(\mathrm{Nu})$. Adluminal compartment with round spermatids (RS) of normal morphology juxtaposed with Sustentocytes cell prolongation (asterisk). Normal blood-testis barrier (B). Normal basement membrane (BM) and peritubular myoid cell (filled arrow head). b. Detail of cytoplasmic bridge (filled arrow) between primary spermatocytes (SP). c. Elongated spermatids (ES) showing nucleus with condensed chromatin. Midpiece (MP) with axoneme surrounded by round mitochondria (M). d. Seminiferous tubule lumen ( $\mathrm{Lu})$ with spermatozoa showing head with acrosomal curvature (not filled arrow), midpiece and flagellum. d-inset. Cross-sections of the sperm tail (end piece) showing axoneme (A) covered by flagellar membrane (not filled arrow head). e-f. Irradiated testes displaying tissue disorganization, germ cells death and vacuolization of the germinal ephitelium (V). Sustentocytes cells showing irregular nucleus with many invaginations in the nuclear membrane and cytoplasm with mitochondrial degeneration (losangue) and dilatation of smooth endoplasmic reticulum cysternas ( $>$ ). Surviving spermatogonium (SG) between the Sustentocytes cells. Disorganization of the blood-testis barrier. Folding (star) and thickening of tubule basement membrane. The nucleus of the peritubular myoid cell appears irregular. 


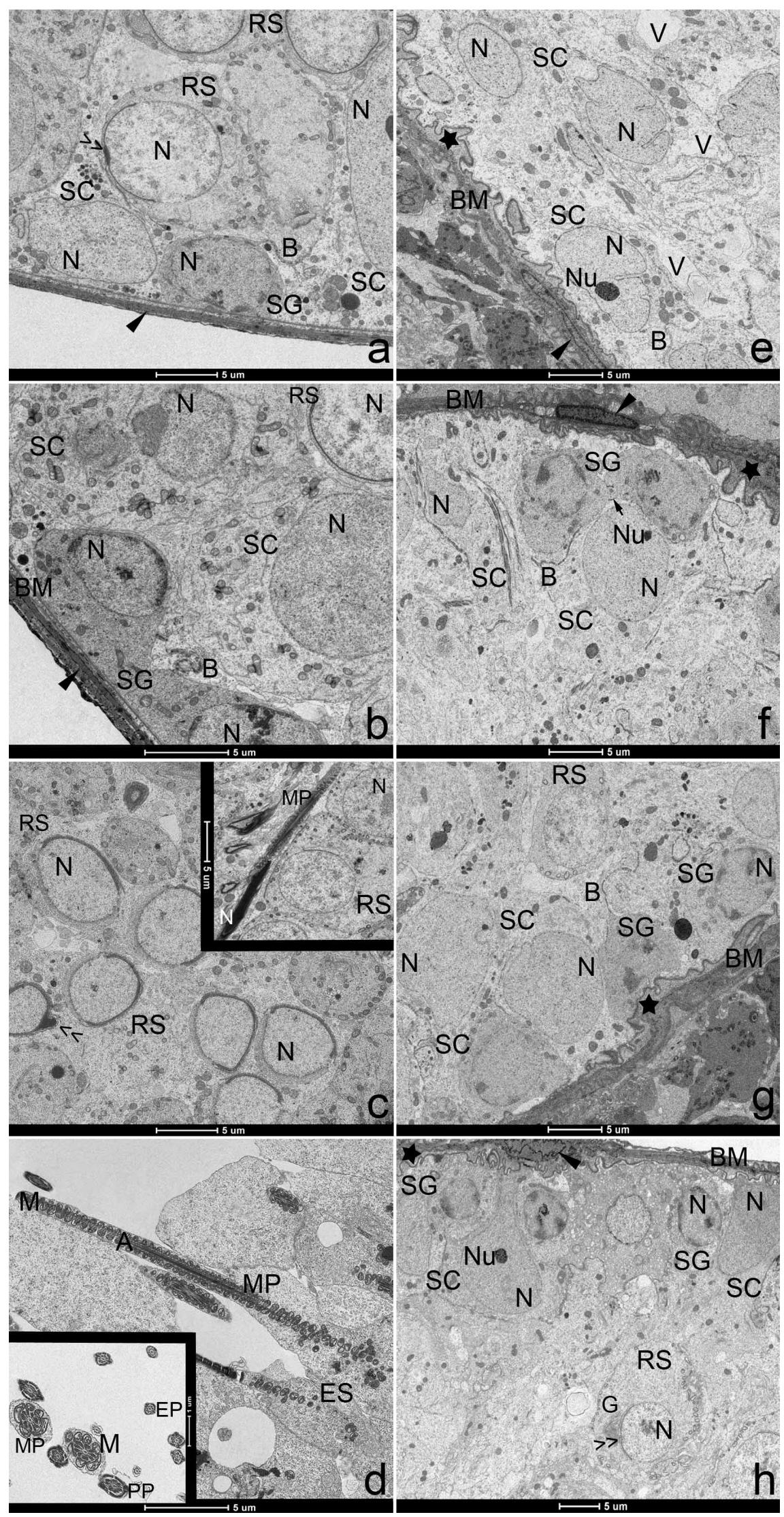

824
Sustentocytes cells and interstitial tissue. However, the damage observed was not to the same magnitude as that which was observed in the group which was only irradiated (Figs. 1e-h, 2e-f, 3e). Furthermore, we observed significantly reduced histopathological changes due to ionizing radiation among the degenerated seminiferous tubules (Figs. 2g-h, 3f-h). These tubules showed signs of recovery of the seminiferous epithelium, evidenced by the presence of spermatogonia,

Fig. 2. Transmission electron micrographs of testes from Telmisartan (a-d) and 5 Gy + Telmisartan groups (ef). a-c: Basal compartment showing spermatogonium (SG), Sustentocytes cell (SC) and normal blood-testis barrier (B). Adluminal compartment with round spermatid (RS) displaying normal acrosomal cap formation ( $>$ ). Normal basement membrane (BM) and peritubular myoid cell (filled arrow head). c-inset. Elongated spermatid (ES) showing elongated nucleus $(\mathrm{N})$ with condensed chromatin, midpiece (MP) and flagellum. d. Detail of elongated spermatids midpiece with many mitochondria (M) surrounding the axoneme (A). d-inset. Cross-sections of midpiece and principle (PP) and end pieces (EP) of the sperm tail. e-f. Irradiation-treated with Telmisartan rat testes displaying better preserved structure of seminiferous tubules. Decrease of vacuolization (V) in the germinal ephitelium. Sustentocytes cells keeping irregular nucleus with many invaginations in the nuclear membrane, but returning to the basement membrane together with the spermatogonia. Reorganization of the blood-testis barrier. In the adluminal compartment, round spermatids with normal acrosomal cap development. Maintenance of folding (star) and thickening of tubule basement membrane. Nucleus of the peritubular myoid cell relatively elongated. $\mathrm{G}=$ Golgi complex; $\mathrm{Nu}=$ nucleolus; Filled arrow $=$ cytoplasmic bridge. 

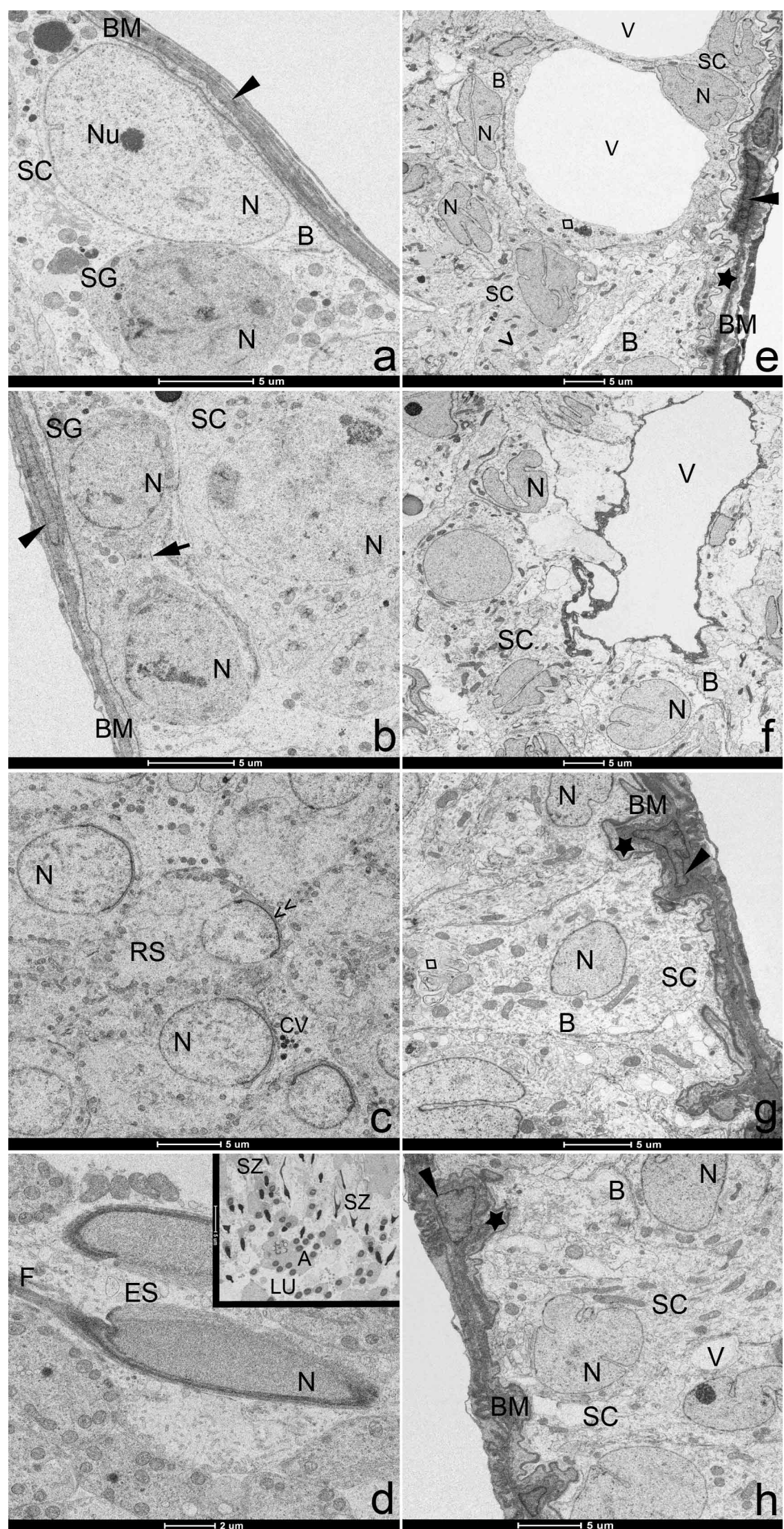

primary spermatocytes and spermatids; all of which indicate the resumption of spermatogenesis. There was also a reduction in the size and quantity of vacuoles in the epithelium. In these tubules, it appeared that the reorganization of the seminiferous epithelium began in the tubular periphery, with Sustentocytes cells and spermatogonia (stem cells) resting on the basement membrane, and the reestablishment of the bloodtestis barrier (Figs. 2g-h, 3f-h).

Fig. 3. Transmission electron micrographs of testes from Losartan (a-d) and $5 \mathrm{~Gy}+$ Losartan groups (e-f). a, b: Basal compartment showing spermatogonium (SG), Sustentocytes cell (SC) and normal blood-testis barrier (B). Normal basement membrane $(\mathrm{BM})$ and peritubular myoid cell (filled arrow head). c. Adluminal compartment with round spermatid (RS) displaying normal acrosomal cap formation (>>). d-inset. Elongated spermatid (ES) showing elongated nucleus (N) with chromatin in condensation and flagellum (F). Lumen region displaying spermiation and usual amount of cytoplasm around the axoneme (A). e-f. Irradiationtreated with Losartan rat testes showing gradative recuperation of seminiferous tubules. e, f. Seminiferous tubules keeping evidence of structural desorganization and vacuolization (V). Degeneratives signs in Sustentocytes cells cytoplasm. g, h. Decrease of vacuolization in the germinal ephitelium. Sertoli cells keeping irregular nucleus with invaginations in the nuclear membrane, but returning toward the basement membrane. Reorganization of the blood-testis barrier. Maintenance of folding (star) and thickening of tubule basement membrane. Nucleus of the peritubular myoid cell keeping irregular shape. $\mathrm{CV}=$ compact vesicles; $\mathrm{LU}=$ lumen; $\mathrm{Nu}=$ nucleolus; SZ = espermatozoon; Losangue $=$ mitochondrial degeneration; $(>)=$ dilatation of smooth endoplasmic reticulum cysternas; Filled arrow = cytoplasmic bridge. 


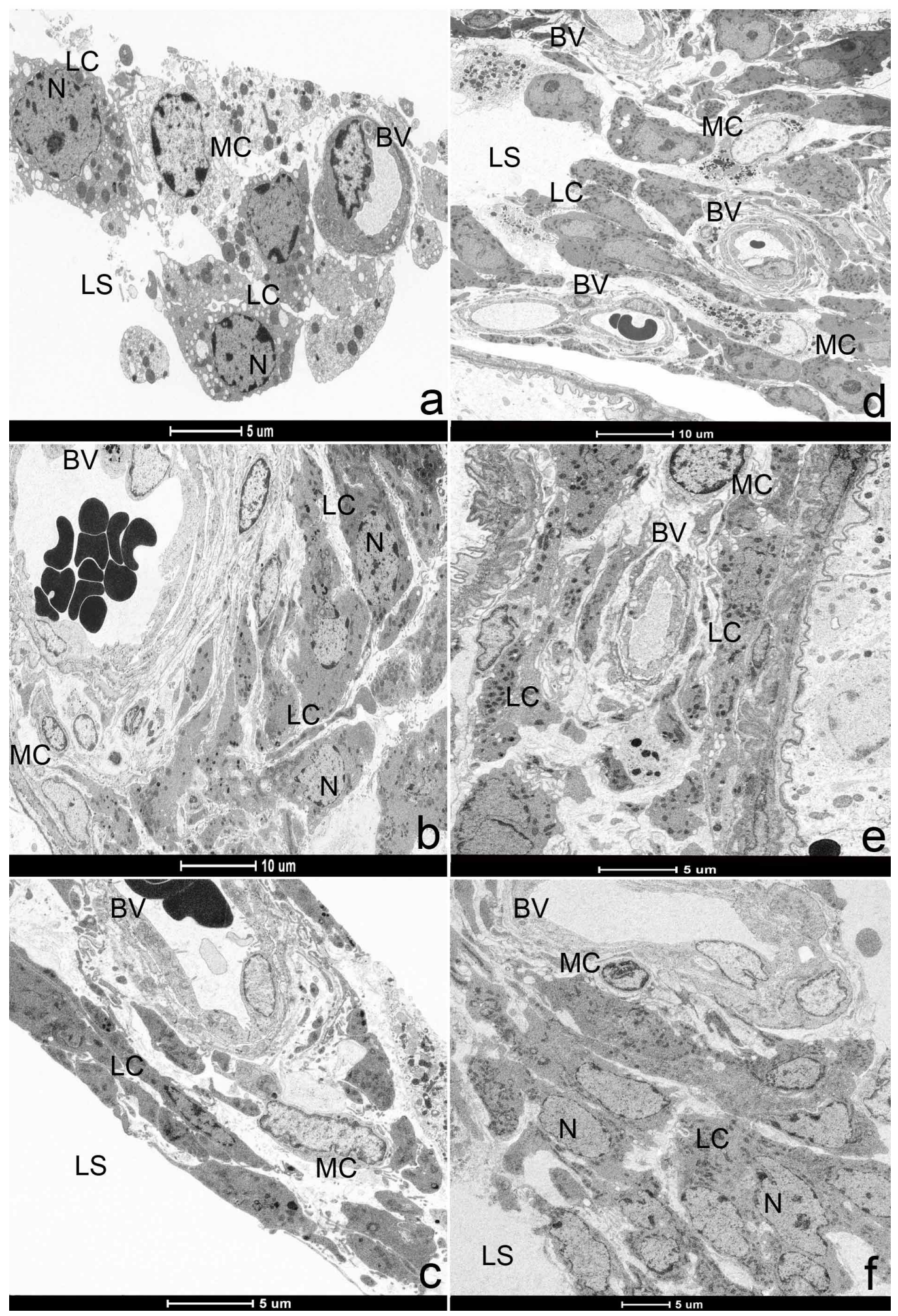

Fig. 4. Transmission electron micrographs of interstitial region. Control (a), Telmisartan (b) and Losartan (c) groups, showing normal morphology. Irradiated with $5 \mathrm{~Gy}(\mathrm{~d})$ and irradiation-treated with Telmisartan (e) and Losartan groups (f), exhibiting increase of vascularization, with some blood vessels of irregular morphology. Note in all images, the presence of insterstitial endocrine cell (LC) organized in clusters of polymorphic cells, blood vessels (BV), lymphatic space (LS) and macrophages (MC). 


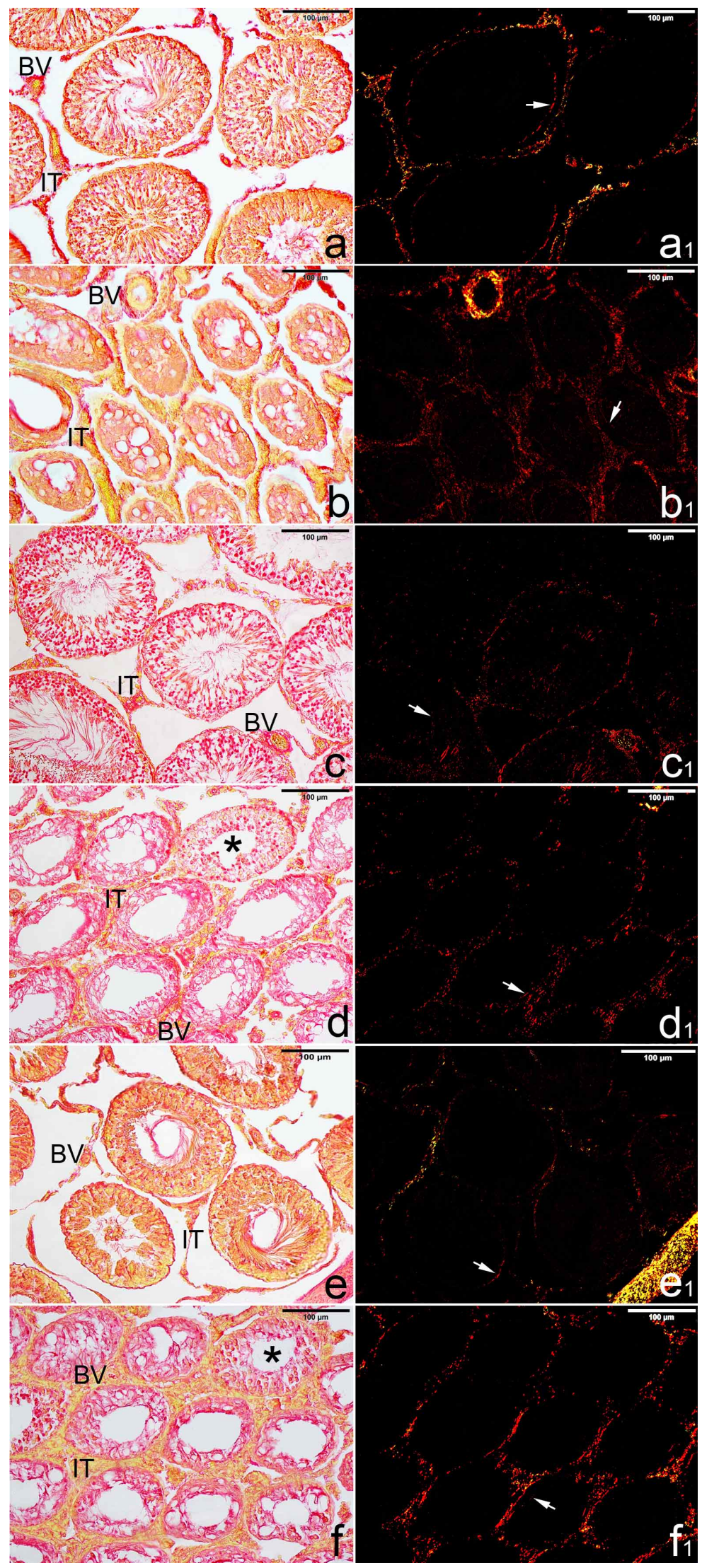

Even with administration of these treatments, the thickening and folding of the basement membrane of the seminiferous tubules persisted. Yet, the peritubular myoid cells exhibited morphology with a tendency towards reestablishing the elongated nuclear shape (Figs. $2 \mathrm{f}, 3 \mathrm{e})$. A reduction in cytoplasmic degeneration was observed in Sustentocytes cells, but the majority of the cells still exhibited irregularly shaped nuclei, similar to those seen in the $5 \mathrm{~Gy}$ group (Figs. 2g, 3h). Concerning the interstitial tissue, there was no attenuation of the changes seen in vascular density when compared to the irradiated without treatment group (Figs. 4d-f).

Collagen evaluation under polarized light. In all the groups, the picrosirius-red stained sections of testis under polarized light showed an evident birefringent basement membrane, surrounding the seminiferous tubules. The interstitial tissue and peritubular region of the irradiated groups presented rich accumulation of collagen fibers in relation to the controls groups, especially the irradiated and nontreated testes (Figs. 5a-f).

Serum testosterone. No significant difference was detected on serum testosterone concentrations among the studied experimental groups (Table I).
Fig. 5. Photomicrographs of testes from Control (a, a1), 5 Gy (b, b1), Telmisartan (c, c1), 5 Gy + Telmisartan (d, d1), Losartan (e, e1) and 5 Gy + Losartan (f, f1) groups subjected to Picrosiriuspolarization method. Note in the groups, the evident birefringent basement membrane (filled arrows). Mainly in the irradiated groups, rich collagen fibers inside testicular interstitium are marked in red, corresponding to collagen deposition under normal (left side) and polarized light (right side). IT = interstitial tissue; $\mathrm{BV}=$ blood vessels; Asterisk = seminiferous tubules in regeneration. 
SCHWARZ, F. C.; MANSANO, N. S.; CHIES, A. B.; VIANI, G. A. \& SPADELLA, M. A. Potential radioprotective effect of AT, receptor antagonists against morphological and ultrastructural changes in the testes induced by ionizing radiation. Int. J. Morphol., 35(3):820-830, 2017.

Table I. Serum testosterone concentrations among the experimental groups.

\begin{tabular}{|c|c|c|c|c|c|c|}
\hline & \multicolumn{6}{|c|}{ Experimental groups } \\
\hline & Control & 5 Gy & Telmisartan & $\begin{array}{c}5 \text { Gy }+ \\
\text { Telmisartan }\end{array}$ & Losartan & $\begin{array}{c}5 \text { Gy + } \\
\text { Losartan }\end{array}$ \\
\hline $\begin{array}{l}\text { Serum testosterone } \\
(\mathrm{ng} / \mathrm{mL})\end{array}$ & $277.9 \pm 181.2$ & $288.8 \pm 134.5$ & $379.5 \pm 302.8$ & $234.3 \pm 134.3$ & $409.8 \pm 220.8$ & $245.4 \pm 226.4$ \\
\hline
\end{tabular}

Values expressed as mean \pm SD. $p \geq 0.05$; parametric two-way ANOVA followed by the Tukey test. Comparison of groups Control versus 5 Gy gamma rays; Telmisartan versus 5 Gy gamma rays + Telmisartan; Losartan versus 5 Gy gamma rays + Losartan.

\section{DISCUSSION}

Radiotherapy is one of the most common forms of cancer treatment. Although it is beneficial in the treatment and/or management of tumors, it can also cause significant tissue damage, which has negative effects on patient quality of life. Reproductive organs is one of the most radiosensitive types of tissue. Various studies have shown the deleterious effects of ionizing radiation on male fertility (Koruji et al.; Meistrich; Aktoz et al., 2016).

In this study, ultrastructural analysis revealed the extent to which ionizing radiation can cause testicular damage. These findings were in line with those of previous studies done on irradiated testes (Koruji et al.; TopcuTarladacalisir et al.; Kanter et al.; Kim et al.). We observed complete tissue breakdown and degeneration of the seminiferous epithelium - which led to its vacuolization by way of germ cell death - as well as the interruption of spermatogenesis. These alterations then lead to the atrophy of the seminiferous tubules, which is a common characteristic of testes exposed to radiation (Ding et al., 2015).

Germ tissue integrity and homeostasis in the adluminal compartment are essential for spermatogenesis. These two qualities depend upon adequate establishment of the blood-testis barrier, which is made up of several types of cell junctions - including tight junctions between adjacent Sustentocytes cells, and adhesion junctions between Sustentocytes and germ cells (Ding et al.; Jiang et al., 2014). In this study, ionizing radiation promoted the degeneration of the germinal epithelium, which resulted in the breakdown of the blood-testis barrier. According to Ha et al. (2011), one of the causes of radiation-induced damage to this barrier are the ROS formed as a result of radiation action on the tissue. These ROS attack essential components of the cell junctions' functionality, such as the E-cadherin and alphacatenin proteins, which in turn interferes with its permeability.

Ultrastructural data also revealed tubular fibrosis due to thickening of the basement membrane surrounding the seminiferous tubules. Topcu-Tarladacalisir et al. reported that the increased production of extracellular matrix has been considered a defense reaction that tissue employs against free radicals. This could explain the thickening of the basement membrane in irradiated testes, which may also be a response to oxidative stress.

In addition to affecting the seminiferous tubules, radiation of the testes also led to histopathological changes in the interstitial tissue in the present study. These changes were characterized by increased density and vascular alterations. According to Grabham \& Sharma (2013), the excessive vascularization of irradiated tissues can be explained by the fact that radiation evokes angiogenesis due to the imbalance between pro and anti-angiogenic factors. Moreover, the interstitium showed signs of expansion among the seminiferous tubules when compared to the control groups. This occurrence was most likely due to intense tubular atrophy.

Regarding the telmisartan and losartan treatments, the ultrastructural data of the present study showed strong evidence of gonadal restructuring and slow, gradual recovery of the spermatogenic process in irradiated testes. The presence of cells in advanced stages of development in the seminiferous epithelium - such as primary spermatocytes and even early spermatids - indicated this cellular renewal. Despite this initial recuperation, tubular atrophy and fibrosis were still present, as the proliferative activity of the seminiferous epithelium did not reach high enough levels to promote complete restructuring of the seminiferous tubule. The AT1 receptor antagonists were also unable to attenuate the thickening and folding of the basement membrane. The persistence of these dysfunctions was also observed in other studies on the treatment of irradiated testes with antioxidants (TopcuTarladacalisir et al.; Kanter et al.).

Prior studies have shown that testicular recovery depends upon stem spermatagonias' survival, self-renewal and capacity to differentiate and repopulate the gonad in the face of radiation (Topcu-Tarladacalisir et al.; Meistrich). The 
present study corroborates these findings, as the ultrastructure of the irradiated and treated testes showed a restructuring of the seminiferous tubules with an organization of Sustentocytes cells and spermatogonia in the basement membrane, as well as the reestablishment of the blood-testis barrier. In addition, telmisartan and losartan treatments attenuated the cytoplasmic degeneration of Sustentocytes cells. However, they did not influence nuclear shape, which continued to be irregular.

The evaluation of collagen content revealed rich deposition of fibers in the interstitial region of the irradiated testes. This finding was particularly marked in the group submitted to radiation only. According to Zhu et al. (2015), the abnormal interstitial accumulation of collagen and fibrosis formation can result in steroidogenic dysfunction in insterstitial endocrine cell. Then, the authors hypothesize that low level of collagen Type I in extracelular matrix present in the interstitium contribute for the normal occurrence of steroidogenesis.

Despite the accumulation of collagen was observed in the interstitium from irradiated groups, serum testosterone concentrations did not indicate testicular interstitial dysfunction. Thus, there was not a significant reduction in the serum testosterone levels of irradiated animals when compared to controls. Evidently, neither ionizing radiation, which effectively reduces testosterone levels (Ding et al.), nor interstitial fibrogenesis interfered with insterstitial endocrine cell steroidogenesis in these experimental groups.

Interestingly, studies have shown that Ang II's role in the testes relates to the inhibition of insterstitial endocrine cell function by way of the AT1 receptor. This suggests that local Ang II production could negatively modulate the stimulation of insterstitial endocrine cell occasioned by pituitary luteinizing hormone (Sernia \& Leung, 2003). In this study, the administration of Ang II AT1 receptor antagonists may have influenced the non-inhibition of insterstitial endocrine cell. Consequently, their steroidogenic activity in the irradiated and treated testes was largely unaffected. It is possible that the pharmaceuticals acted as protectors of insterstitial endocrine cell function, and therefore prevented a drastic reduction in testosterone levels due to the radiation.

In conclusion, we demonstrated that telmisartan and losartan treatments may attenuate radiation-induced changes in testicular morphology and ultrastructure, by accelerating the reorganization and recolonization of the seminiferous tubules. Given these findings, employing a longer duration of treatment may lead to more positive effects. Therefore, complementary studies should be designed to maximize these effects and better characterize the radioprotection along reproductive parameters.
Thus, new perspectives open for the larger investigation surrounding the intrinsic RAS of the testes and the potential benefits that treatment with AT1 receptor antagonists - before, during or after radiotherapy — could bring for male fertility. The hypothesis that telmisartan and losartan are able to minimize the testicular damage occasioned by radiation, possibly due to their roles as antioxidants, merits further exploration.

ACKNOWLEDGEMENTS. This research was supported by Brazilian agency - FAPESP (Fundação de Amparo à Pesquisa do Estado de São Paulo), grant \#2015/20740-4.

SCHWARZ, F. C.; MANSANO, N. S.; CHIES, A. B.; VIANI, G. A. \& SPADELLA, M. A. Potencial efecto radioprotector de antagonistas del receptor $\mathrm{AT}_{1}$ contra los daños morfológicos y ultraestructurales en los testículos inducido por la radiación ionizante. Int. J. Morphol., 35(3):820-830, 2017.

RESUMEN: El tratamiento radioterápico es una fuente de exposición del ser humano a la radiación ionizante. Esta energía pura causa efectos deletéreos en los tejidos, debido al estrés oxidativo, fenómeno donde hay participación del Sistema Renina-Angiotensina. Los órganos genitales masculinos son extremadamente radiosensibles y la acción de la radiación en los testículos puede afectar significativamente la espermatogénesis. En la búsqueda de potenciales radioprotectores, este estudio ha investigado fármacos antagonistas del receptor AT1 que minimizan los daños radioinduzidos en los tejidos reproductivos, por medio de la disminución del estrés oxidativo. Ratones Wistar machos fueron distribuidos en seis grupos: grupo 0 Gray (Gy) (control), grupo 5 Gy (dosis única en el área escrotal), grupo telmisartán, grupo losartán, grupo 5Gy+telmisartán y grupo $5 \mathrm{Gy+losartán.} \mathrm{El} \mathrm{tratamiento} \mathrm{empezó} \mathrm{en} \mathrm{el} \mathrm{día} \mathrm{siguiente} \mathrm{a} \mathrm{la} \mathrm{irradia-}$ ción con losartán $34 \mathrm{mg} / \mathrm{kg}$ (2x/día) y telmisartán $12 \mathrm{mg} / \mathrm{kg}$ (1x/día), durante 60 días. Para el análisis ultraestructural, los testículos se fijaron en glutaraldehido (2\%) y paraformaldehido (4\%) con tampón de fosfato $0,1 \mathrm{M}, \mathrm{pH} 7,3$. El material fue post-fijado en tetróxido de osmio (1\%). Para evaluar el colágeno fue utilizado el método Picrosirius Red. Fue determinada la concentración sérica de testosterona. Los datos mostraron los efectos deletéreos de los rayos gamma sobre la ultraestructura testicular. Fue observada una rica deposición de colágeno en el intersticio en los grupos irradiados, especialmente en el irradiado y no tratado. Entre los grupos, no se detectó ninguna diferencia significativa en la concentración sérica de testosterona. Los tratamientos con telmisartán y losartán influenciaron el comienzo de la atenuación de los cambios en la ultraestructura testicular de la radiación. A pesar de que los datos sugieren que los antagonistas del receptor AT1 pueden promover radioprotección a los testículos, estudios complementarios con una duración de tratamiento más extendida son necesarios para que los efectos potencialmente positivos sean maximizados y, por supuesto, puedan mejorar la caracterizacion de la radioprotección a los parámetros reproductivos.

PALABRAS CLAVE: Radiación ionizante; Ultraestructura testicular; Espermatogénesis; Sistema Renina-Angiotensina; Estrés oxidativo; bloqueadores de los receptores AT1 de la Angiotensina II. 
SCHWARZ, F. C.; MANSANO, N. S.; CHIES, A. B.; VIANI, G. A. \& SPADELLA, M. A. Potential radioprotective effect of AT receptor antagonists against morphological and ultrastructural changes in the testes induced by ionizing radiation. Int. J. Morphol., 35(3):820-830, 2017.

\section{REFERENCES}

Aktoz, T.; Caloglu, M.; Yurut-Caloglu, V.; Yalcin, O.; Aydogdu, N.; Nurlu, D.; Arda, E. \& Inci, O. Histopathological and biochemical comparisons of the protective effects of amifostine and 1-carnitine against radiationinduced acute testicular toxicity in rats. Andrologia, 2016. In press.

Bauché, F.; Fouchard, M. H. \& Jégou, B. Antioxidant system in rat testicular cells. F. E. B. S. Lett., 349(3):392-6, 1994.

Benigni, A.; Cassis, P. \& Remuzzi, G. Angiotensin II revisited: new roles in inflammation, immunology and aging. E. M. B. O. Mol. Med., 2(7):247-57, 2010.

Ding, J.; Wang, H.; Wu, Z. B.; Zhao, J.; Zhang, S. \& Li, W. Protection of murine spermatogenesis against ionizing radiation-induced testicular injury by a green tea polyphenol. Biol. Reprod., 92(1):6, 2015.

Fujii, J.; Iuchi, Y.; Matsuki, S. \& Ishii, T. Cooperative function of antioxidant and redox systems against oxidative stress in male reproductive tissues. Asian J. Androl., 5(3):231-42, 2003.

Grabham, P. \& Sharma, P. The effects of radiation on angiogenesis. Vasc. Cell., 5(1):19, 2013.

Greene-Schloesser, D.; Robbins, M. E.; Peiffer, A. M.; Shaw, E. G.; Wheeler, K. T. \& Chan, M. D. Radiation-induced brain injury: A review. Front. Oncol., 2:73, 2012.

Ha, H. K; Park, H. J. \& Park, N. C. Expression of E-cadherin and a-catenin in a varicocele-induced infertility rat model. Asian J. Androl., 13(3):4705,2011

Jiang, X. H.; Bukhari, I.; Zheng, W.; Yin, S.; Wang, Z.; Cooke, H. J. \& Shi, Q. H. Blood-testis barrier and spermatogenesis: lessons from geneticallymodified mice. Asian J. Androl., 16(4):572-80, 2014.

Kanter, M.; Topcu-Tarladacalisir, Y. T. \& Parlar, S. Antiapoptotic effect of L-carnitine on testicular irradiation in rats. J. Mol. Histol., 41(2-3):1218, 2010.

Kharofa, J.; Cohen, E. P.; Tomic, R.; Xiang, Q. \& Gore, E. Decreased risk of radiation pneumonitis with incidental concurrent use of angiotensinconverting enzyme inhibitors and thoracic radiation therapy. Int. $J$. Radiat. Oncol. Biol. Phys., 84(1):238-43, 2012.

Kim, J. S.; Heo, K.; Yi, J. M.; Gong, E. J.; Yang, K.; Moon, C. \& Kim, S. $\mathrm{H}$. Genistein mitigates radiation-induced testicular injury. Phytother. Res., 26(8):1119-25, 2012.

Koruji, M.; Movahedin, M.; Mowla, S. J.; Gourabi, H. \& Arfaee, A. J. The morphological changes of adult mouse testes after 60Co gammaRadiation. Iran. Biomed. J., 12(1):35-42, 2008.

Kushwaha, S. \& Jena, G. B. Telmisartan ameliorates germ cell toxicity in the STZ-induced diabetic rat: studies on possible molecular mechanisms. Mutat. Res., 755(1):11-23, 2013.

Leung, P. S. \& Sernia, C. The renin-angiotensin system and male reproduction: new functions for old hormones. J. Mol. Endocrinol., 30(3):263-70, 2003.

Li, M.; Liu, Z.; Zhuan, L.; Wang, T.; Guo, S.; Wang, S.; Liu, J. \& Ye, Z. Effects of apocynin on oxidative stress and expression of apoptosisrelated genes in testes of diabetic rats. Mol. Med. Rep., 7(1):47-52, 2013.

Meistrich, M. L. Effects of chemotherapy and radiotherapy on spermatogenesis in humans. Fertil. Steril., 100(5):1180-6, 2013.

Montes, G. S. \& Junqueira, L. C. The use of the Picrosirius-polarization method for the study of the biopathology of collagen. Mem. Inst. Oswaldo Cruz, 86 Suppl. 3:1-11, 1991.

Morais, G. B.; Viana, D. A.; Silva, F. M. O.; Xavier Júnior, F. A. F.; Farias, K. M.; Pessoa, C. D.; Silveira, J. A. M.; Alves, A. P. N. N.; Mota, M. R. L.; Silva, F. D. O.; Sampaio, C. M. S.; Verdugo, J. M. G. \& Evangelista, J.S.A. M. Polarization microscopy as a tool for quantitative evaluation of collagen using picrosirius red in different stages of CKD in cats. Microsc. Res. Tech., 80(5):543-50, 2017.

Nair, C. K.; Parida, D. K. \& Nomura, T. Radioprotectors in radiotherapy. J. Radiat. Res., 42(1):21-37, 2001.

Robbins, M. E. \& Diz, D. I. Pathogenic role of the renin-angiotensin system in modulating radiation-induced late effects. Int. J. Radiat. Oncol. Biol. Phys., 64(1):6-12, 2006.

Robbins, M. E. \& Zhao, W. Chronic oxidative stress and radiation-induced late normal tissue injury: a review. Int. J. Radiat. Biol., 80(4):251-9, 2004.

Speth, R. C.; Daubert, D. L. \& Grove, K. L. Angiotensin II: a reproductive hormone too? Regul. Pept., 79(1):25-40, 1999.

Topcu-Tarladacalisir, Y.; Kanter, M. \& Uzal, M. C. Role of L-carnitine in the prevention of seminiferous tubules damage induced by gamma radiation: a light and electron microscopic study. Arch. Toxicol., 83(8):735-46, 2009

Zhu, C. C.; Tang, B.; Su, J.; Zhao, H.; Bu, X.; Li, Z.; Zhao, J.; Gong, W. D.; Wu, Z. Q.; Yao, L. B.; Li, W. \& Zhang, Y. Q. Abnormal accumulation of collagen type I due to the loss of Discoidin domain receptor 2 (Ddr2) promotes testicular interstitial dysfunction. PLoS One, 10(7):e0131947, 2015.

Corresponding author

Profa. Dra. Maria Angélica Spadella

Faculdade de Medicina de Marília

Disciplina Embriologia Humana

Av. Monte Carmelo, 800 - Fragata

CEP: 17.519-030 CP: 2003

Marília, São Paulo

BRAZIL

E-mail: maspadella@gmail.com

Received: 19-02-2017

Accepted: 10-04-2017 